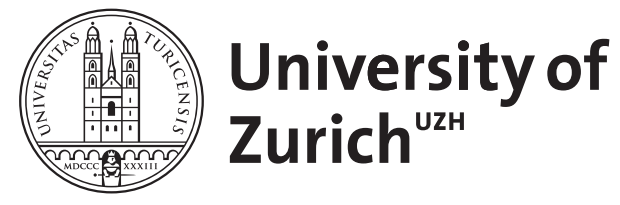

Zurich Open Repository and Archive

University of Zurich

Main Library

Strickhofstrasse 39

CH-8057 Zurich

www.zora.uzh.ch

Year: 2016

\title{
Zeolite A effect on calcium homeostasis in growing goats
}

Schwaller, Daniela

Posted at the Zurich Open Repository and Archive, University of Zurich

ZORA URL: https://doi.org/10.5167/uzh-133343

Originally published at:

Schwaller, Daniela. Zeolite A effect on calcium homeostasis in growing goats. 2016, University of Zurich, Vetsuisse-Fakultät. 


\author{
Institut für Tierernährung \\ der Vetsuisse-Fakultät Universität Zürich
}

Direktorin: Prof. Dr. med. vet. Annette Liesegang

Zeolite A effect on calcium homeostasis in growing goats

Inaugural-Dissertation

zur Erlangung der Doktorwürde der

Vetsuisse-Fakultät Universität Zürich

vorgelegt von

\title{
Daniela Schwaller
}

\author{
Tierärztin \\ von Recherswil SO
}

genehmigt auf Antrag von

Prof. Dr. med. vet. Annette Liesegang, Referentin 
Meinen Eltern! 


\section{Inhaltsverzeichnis}

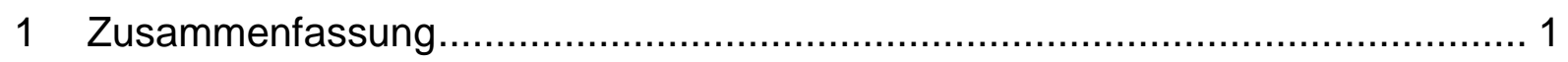

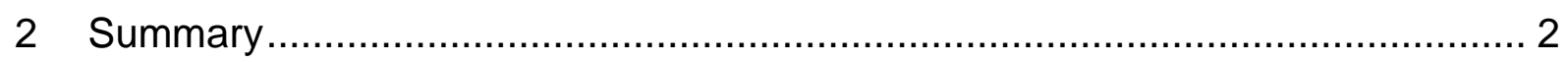

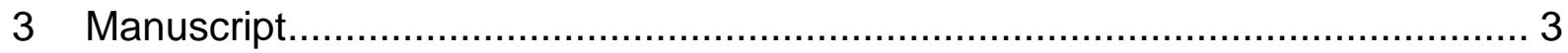

3.1 Authors, correspondence and acknowledgments................................... 3

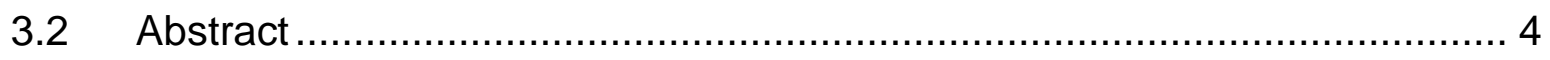

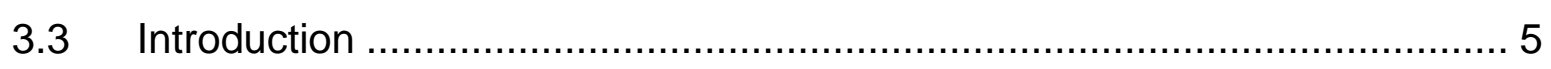

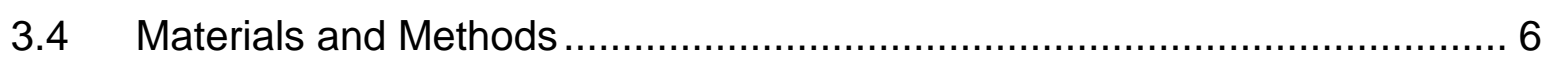

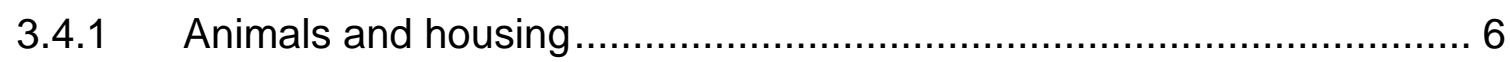

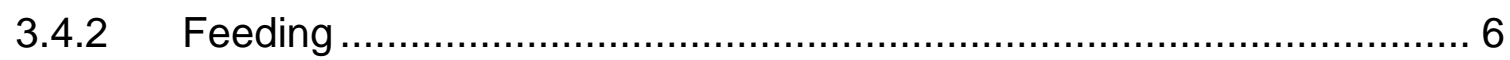

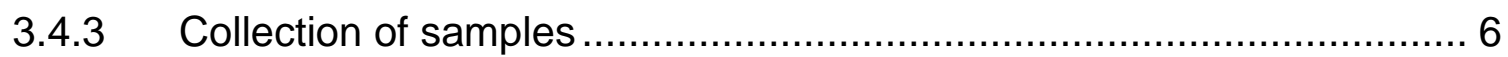

3.4.4 Analysis of serum and urine samples.............................................. 7

3.4.5 Ussing chamber technique....................................................... 8

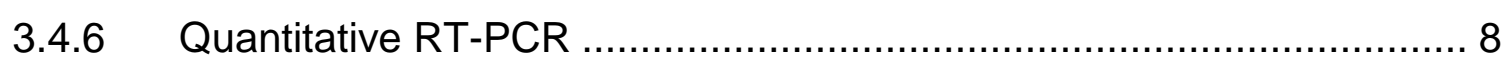

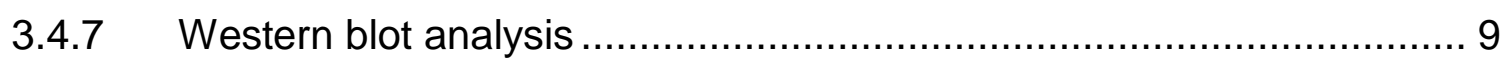

3.4.8 Peripheral quantitative computed tomographie (pQCT) ................... 10

3.4.9 Statistical analysis .................................................................... 10

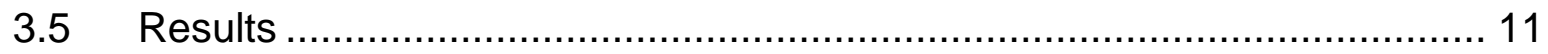

3.5.1 Feed intake and live weight changes ........................................ 11

3.5.2 Serum concentrations of minerals................................................ 11

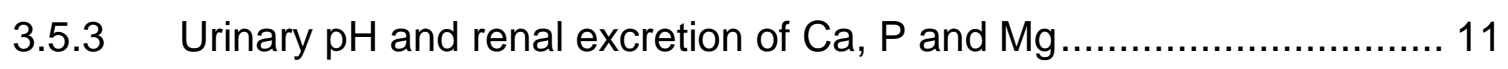

3.5.4 Serum concentrations of vitamin D metabolites ................................ 11

3.5.5 Analysis of bone parameters: Serum concentrations of $\mathrm{SCL}$ and $\mathrm{OC}$;

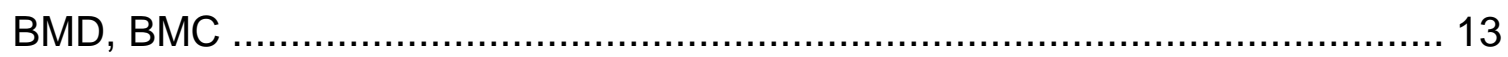

3.5.6 Ussing chamber experiments................................................... 13

3.5.7 Expression of VDR, 1 $\alpha$-hydroxylase and structures involved in transcellular Ca transport ....................................................................... 19

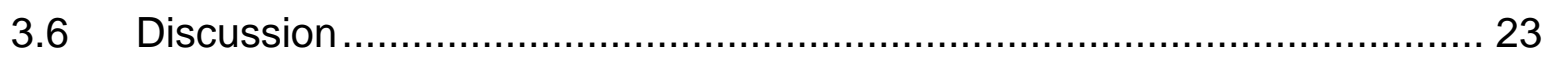

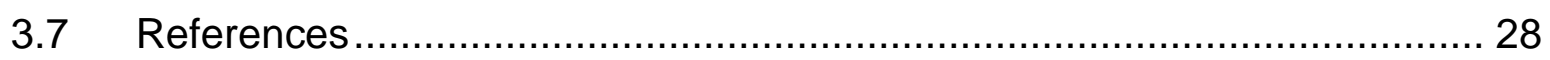

4 Danksagung.

5 Lebenslauf. 


\section{Zusammenfassung}

Das Ziel dieser Arbeit war es, die Wirkungsweise von Zeolith A in zwei unterschiedlichen Dosierungen auf den Calciumstoffwechsel von Wiederkäuern zu untersuchen. Siebzehn wachsende Ziegen wurden in drei Gruppen unterteilt. Während die Kontrollgruppe keinen Zusatz erhielt, wurden die beiden Versuchsgruppen entweder mit $1.2 \mathrm{~g} / \mathrm{kg}$ oder $1.6 \mathrm{~g} / \mathrm{kg}$ Körpergewicht Zeolith ergänzt. In regelmässigen Abständen wurden Blut- und Unrinproben entnommen und einmal wöchentlich wurde die Knochendichte mittels Computertomographie bestimmt. Nach drei Wochen wurden die Tiere geschlachtet und Gewebeproben von Pansen, Duodenum und Nieren entnommen. Es konnten keine signifikanten Gruppenunterschiede bezüglich Plasma-Calcium-Konzentrationen gemessen werden. Hingegen zeigten beide Versuchsgruppen deutlich geringere Konzentrationen an Phosphat, Magnesium und 1,25-Dihydroxycholecalciferol im Plasma. Obwohl in beiden Versuchsgruppen die Knochenresorptionsrate erhöht war, zeigten die Tiere keine Unterschiede in der Knochenstruktur. Weder die gastrointestinale Calciumabsorption, gemessen mittels Ussing-Kammer, noch die Quantifizierung der RNA- und Proteinexpression der daran beteiligten Gene zeigten einen stimulierenden Effekt von Zeolith. Trotzdem sollten die Effekte von Zeolith auf 1,25-Dihydroxycholecalciferol, den Knochenstoffwechsel und die Serumkonzentrationen von Phosphat und Magnesium immer bedacht werden, wenn eine Ration mit Zeolith an Wiederkäuer verfüttert wird. 


\section{Summary}

The purpose of this study was to investigate the influence of two different concentrations of zeolite A on calcium homeostasis of ruminants. Seventeen growing goats were divided into three groups. While the control group received no addition, zeolite $A$ at either $1.2 \mathrm{~g} / \mathrm{kg}$ or $1.6 \mathrm{~g} / \mathrm{kg}$ body weight, respectively, was added to the two treatment groups. Blood and urine samples were drawn continually and bone mineral density was measured weekly by peripheral quantitative computed tomography. After three weeks, the animals were slaughtered and samples were taken from the rumen, duodenum and kidneys. Plasma calcium concentrations were not altered. Plasma concentrations of phosphate, magnesium and 1,25dihydroxycholecalciferol as well as renal excretion of phosphate were significantly lower in the treatment groups compared to the control group. Although bone resorption was increased in both treatment groups no alterations in bone structure were detected. Determination of gastrointestinal absorption of calcium by Ussing chamber technique and quantification of RNA and protein expression of genes known to be involved in active calcium absorption did not reveal any stimulating effect of zeolite. However, the effects on 1,25-dihydroxycholecalciferol, bone metabolism and serum concentrations of phosphate and magnesium shown in the present study should be considered whenever rations with zeolite are designed for ruminants. 


\section{Manuscript}

\subsection{Authors, correspondence and acknowledgments}

Zeolite $\mathrm{A}$ effect on calcium homeostasis in growing goats ${ }^{1}$

D. Schwaller ${ }^{\star}$, M. R. Wilkens ${ }^{\dagger}$, A. Liesegang ${ }^{\star} \neq 2$

* Institute of Animal Nutrition, University of Zurich, 8057 Zurich, Switzerland

† Department of Physiology, University of Veterinary Medicine Hannover, Foundation, 30159 Hannover, Germany

₹ Center for Applied Biotechnology and Molecular Medicine (CABMM), 8057 Zurich, Switzerland

${ }^{1}$ The authors thank Maja Bollhalder and Ines Mittner for the excellent technical assistance. In addition, we thank David R. Fraser for critical revision of the manuscript.

${ }^{2}$ Corresponding author: aliese@nutrivet.uzh.ch, Winterthurerstrasse 270, 8057 Zurich, Switzerland

Published in Journal of Animal Science DOI: 10.2527/jas2015-9690 


\subsection{Abstract}

The purpose of this study was to investigate the influence of two different concentrations of zeolite A on calcium homeostasis. Seventeen growing goats were divided into three groups. While the control group (5 animals) received no supplementation, two treatment groups were supplemented with zeolite $A$ at either $1.2 \mathrm{~g} / \mathrm{kg}$ (6 animals) or $1.6 \mathrm{~g} / \mathrm{kg}$ body weight (6 animals), respectively. Blood and urine samples were drawn continually and bone mineral density was measured weekly by peripheral quantitative computed tomography. After three weeks, the animals were slaughtered and samples were taken from the rumen, duodenum and kidneys. Plasma concentrations of phosphate $(P<0.001)$, magnesium $(P<0.001)$ and 1,25-dihydroxycholecalciferol $(P<0.01)$ as well as renal excretion of phosphate $(P<0.05)$ were significantly lower in the treatment groups compared to the control group. Although bone resorption was increased in both treatment groups $(P<0.05)$ no alterations in bone structure were detected. Determination of gastrointestinal absorption of calcium by Ussing chamber technique and quantification of RNA and protein expression of genes known to be involved in active calcium absorption did not reveal any stimulating effect of zeolite. Plasma calcium concentrations were not altered, probably because of the sufficient dietary calcium supply. However, the effects on 1,25-dihydroxycholecalciferol, bone metabolism and serum concentrations of phosphate and magnesium shown in the present study and thus potential negative long-term effects on the animals should be considered whenever rations with zeolite are designed for ruminants.

Key words: goat, calcium, hypocalcaemia, vitamin $D$, zeolite $A$ 


\subsection{Introduction}

One common approach of preventing periparturient hypocalcaemia in dairy cows is to feed a Ca restricted diet before parturition (Boda and Cole, 1954). The effect on Ca homeostasis results in an enhanced secretion of parathyroid hormone (PTH). By stimulating bone resorption (Goff et al., 1991) as well as the production of 1,25dihydroxycholecalciferol (1,25-(OH)2D) (Hoenderop et al., 2005), the cow is prepared for the sudden increase in $\mathrm{Ca}$ demand at the onset of lactation.

However, the typical ration fed to dairy cows usually contains far more $\mathrm{Ca}$ than the recommended $20 \mathrm{~g}$ per day. Therefore, several studies aimed at the reduction of $\mathrm{Ca}$ availability by adding the synthetic sodium aluminosilicate zeolite $\mathrm{A}$ to bind dietary $\mathrm{Ca}$ have been performed. In several studies, it has been shown that zeolite $A$ supplementation during late gestation stabilizes blood $\mathrm{Ca}$ concentrations around parturition (Thilsing-Hansen and Jorgensen 2001; Thilsing-Hansen et al., 2002; Pallesen et al., 2008; Grabherr et al., 2009).

However, additional effects of zeolite A on plasma P (Enemark et al., 2003; Pallesen et al., 2008) and Mg (Thilsing-Hansen et al., 2002; Grabherr et al., 2009) as well as on urinary $\mathrm{pH}$ and renal excretion of minerals (Thilsing-Hansen et al., 2002) were also reported. Thus, the impact of zeolite $A$ on mineral homeostasis appears more complex than just reducing the availability of $\mathrm{Ca}$ in the ration.

The aim of the present study was to investigate physiological mechanisms and the influence of zeolite $\mathrm{A}$ on ruminal, intestinal and renal $\mathrm{Ca}$ control, vitamin $\mathrm{D}$ metabolism and bone turnover. Goats were used as a model to test the following hypotheses: (1) Zeolite A reduces dietary $\mathrm{Ca}$ availability and therefore $\mathrm{Ca}$ influx into blood during its application. (2) This leads to an increase in 1,25-(OH)2D synthesis (3) and a stimulation of Ca mobilization via the action of PTH. Furthermore, potential side effects on $\mathrm{P}$ and $\mathrm{Mg}$ homeostasis and their resulting influence of $\mathrm{Ca}$ homeostasis were included. 


\subsection{Materials and Methods}

\subsubsection{Animals and housing}

Seventeen growing goats (Saanen type breed, 11 weeks of age, 11 males and 6 females) were randomly assigned to two experimental (6 animals) groups and one control group (5 animals), respectively. Each group included two female and three (control group) or four (experimental group) male animals, respectively. The goat kids were kept in groups on wood shavings without straw. Goats were fed individually in single boxes for accurate monitoring of intake. Body weight was determined every fourth day. After three weeks on the experimental diets, the animals were slaughtered and samples were collected.

\subsubsection{Feeding}

The animals were fed hay (2nd cut) and concentrate (2957 Combifloc, Meliofeed AG, Herzogenbuchsee, Switzerland) according to feeding recommendations of the Swiss National Agriculture Research Institute in Posieux (Arrigo et al., 1999). For the first two weeks of the trial, each animal received $560 \mathrm{~g}$ hay and $200 \mathrm{~g}$ concentrate per day, divided into two feedings. From day 13 of the experiment until the end of the observation period, the amount of hay was increased to $660 \mathrm{~g}$ per day. An hour after each feeding, the refusals were weighed to calculate daily intake. Nutrient content of hay and concentrate (Table 1) were analyzed by proximate analysis (Naumann and Bassler, 1997) or calculated from literature values and manufacturer's data (Arrigo et al., 1999).

Zeolite A (ZP 4A) (sodium aluminosilicate, chemical formula $\mathrm{Na} \times[(\mathrm{AlO} 2) \times$ (SiO2)y]zH2O; Silkem Vertriebs AG, Zug, Switzerland) was added to the concentrate fed to the goats of the two treatment groups at a dosage of either $1.2 \mathrm{~g} / \mathrm{kg} \mathrm{BW}(\mathbf{Z 1 . 2})$ or $1.6 \mathrm{~g} / \mathrm{kg} \mathrm{BW}(\mathbf{Z 1 . 6 )}$, respectively.

\subsubsection{Collection of samples}

Blood samples $(10 \mathrm{~mL})$ were collected in the morning before feeding on $\mathrm{d}$ 0, 2, 4, 7, $10,13,16,19$ and 21 from the vena jugularis externa using a vacutainer system (5 $\mathrm{mL}$, without additives; Greiner Bio-One $\mathrm{GmbH}$, St.Gallen, Switzerland). After 
centrifugation at room temperature $(1,500 \times \mathrm{g}, 20 \mathrm{~min})$, aliquots of serum were stored at $-20^{\circ} \mathrm{C}$ and $-80^{\circ} \mathrm{C}$, respectively.

Spontaneous urine samples were obtained in the morning before feeding on $\mathrm{d} 0,2$, 4, 7, 13 and 19 with plastic cups without additives. After immediate determination of urinary $\mathrm{pH}$ (MA 130 Ion meter, Mettler-Toledo $\mathrm{GmbH}$, Greifensee, Switzerland), samples were stored at $-20^{\circ} \mathrm{C}$ without any preserving agent.

On day 21, the goat kids were slaughtered. The gastrointestinal tract (GIT) was excised within 10 min post mortem and washed with ice-cold saline. Pieces of rumen (RU) and duodenum (DD) were immediately placed in Parson buffer solution (107 $\mathrm{mM} \mathrm{NaCl}, 0.2 \mathrm{mM} \mathrm{NaH} 2 \mathrm{PO} 4,1.8 \mathrm{mM} \mathrm{Na} 2 \mathrm{HPO} 4,4.5 \mathrm{mM} \mathrm{KCl}, 25 \mathrm{mM} \mathrm{NaHCO}$, $1.25 \mathrm{mM} \mathrm{CaCl}$, $1 \mathrm{mM}$ MgSO4, $12.2 \mathrm{mM}$ glucose, pH 7.4 [Parson and Paterson, 1965]) which was aerated with carbogen (95\% O2 and 5\% CO2) and examined by Ussing chamber technique. The mucous membrane of DD was separated from muscular layer by scrapping with glass slides. Mucosa samples of DD as well as renal tissues were snap frozen in liquid nitrogen. Until analysis, the samples were frozen at $-80^{\circ} \mathrm{C}$.

\subsubsection{Analysis of serum and urine samples}

Analysis of $\mathbf{C a}, \mathbf{P}, \mathbf{M g}$ and Creatinine. $\mathrm{Ca}, \mathrm{P}, \mathrm{Mg}$ and Creatinine (Creat) concentrations in serum and urine were determined by well-established colorimetric tests using an autoanalyzer (Cobas Mira Roche autoanalyzer, F. Hoffmann-La Roche Ltd., Basel, Switzerland). Commercial kits based on o-cresolphthalein complexone for $\mathrm{Ca}$, ammonium molybdate for $\mathrm{P}$, xylidyl blue for $\mathrm{Mg}$ and picric acid for Creat (Diatools, Villmergen, Switzerland) were used. The intra- and interassay CVs were $0.62 \%$ to $1.45 \%$ and $1.66 \%$ to $2.70 \%$ for $\mathrm{Ca}, 0.86 \%$ to $1.61 \%$ and $1.07 \%$ to $2.22 \%$ for $\mathrm{P}, 0.83 \%$ to $0.92 \%$ and $1.09 \%$ to $1.43 \%$ for $\mathrm{Mg}$ and $0.83 \%$ to $1.3 \%$ and $0.85 \%$ to $3.63 \%$ for Crea.

Analysis of 1,25-(OH)2D and 25-hydroxycholecalciferol. Commercial RIA kits (Immunodiagnostic systems $\mathrm{GmbH}$, Frankfurt am Main, Germany) were used for analyzing serum concentrations of 1,25-(OH)2D and 25-hydroxycholecalciferol (25OHD). The intra- and interassay CVs were $9.1 \%$ to $10.8 \%$ and $9.6 \%$ to $13.6 \%$ for $1,25-(\mathrm{OH}) 2 \mathrm{D}$ and $5.0 \%$ to $6.1 \%$ and $7.3 \%$ to $8.2 \%$ for $25-\mathrm{OHD}$. 
Analysis of Osteocalcin and Serum CrossLaps. Osteocalcin (OC) concentrations in serum were measured using a commercial EIA kit (Quidel Corporation, San Diego, USA) and Serum CrossLaps (SCL) by a commercial ELISA kit (Immunodiagnostic systems $\mathrm{GmbH}$, Frankfurt am Main, Germany). The intra- and interassay CVs were $4.8 \%$ to $10.0 \%$ and $4.8 \%$ to $9.8 \%$ for $\mathrm{OC}$ and $1.7 \%$ to $3.0 \%$ and $2.5 \%$ to $10.9 \%$ for SCL. The bone formation and resorption markers OC and SCL were validated for goats by Liesegang et al. (Liesegang et al., 2003).

\subsubsection{Ussing chamber technique}

Flux rates of $\mathrm{Ca}$ in $\mathrm{RU}$ and $\mathrm{DD}$ were determined by Ussing chamber technique and were already described by Sidler-Lauff et al. (2010). Uniderectional flux rates were measured $\left(\mathrm{J}_{\mathrm{ms}}\right.$ : mucosal to serosal flux rates and $\mathrm{J}_{\mathrm{sm}}$ : serosal to mucosal flux rates) and net flux rates were calculated $\left(J_{\text {net }}=J_{m s}-J_{s m}\right)$.

\subsubsection{Quantitative RT-PCR}

For quantification of RNA expression, isolation of total RNA and synthesis of cDNA were carried out using commercial kits according to the manufacturers' protocols (Tri Reagent Solution, Ambion, Lucerne, Switzerland; RNeasy Mini-Kit, Qiagen, Hilden, Germany; QuantiTect Reverse Transcription Kits, Qiagen, Hombrechtikon, Switzerland; TaqMan-Reverse Transcription Reagents, Applied Biosystems, Darmstadt, Germany). Concentration and quality of the RNA were determined by UV absorbance.

For quantification of calbindin-D9k (CaBP-9k), vitamin D receptor (VDR) and the house-keeping gene beta-actin, cDNA was mixed with sterile water, TaqMan Fast PCR Universal Master Mix 2x (Applied Biosystems) and custom made probes and primers designed by Applied Biosystems (Actin: sense primer 5'GTGATGGACTCCGGTGACG-3'; antisense primer 5'-CAGGTCCAGACGCAGGAT3'; probe 5'-CCCACACGGTGCCCAT-3'; VDR: sense primer 5'GCAGCAGCGCATCATCAC-3'; antisense primer 5'-TCGGAGTAGGTGTCGTCGTA3'; probe 5'-ACGCCCACCACAAGAC-3'; CaBP-9k: sense primer 5'CCAGTTTGCTGAAGGGTCCAA-3'; antisense primer 5' TCTCCATCTCCATTCTTGTCTAGTTCT-3', probe 5'-CCCTCGATGAGCTTTT-3'). 
Custom made primers were validated by the manufacturing company. Assays were checked for appropriate efficiency (90-105\%) using dilution series of cDNA. Quantitative RT-PCR was carried out using a 7500 Fast Real-Time PCR System (Applied Biosystems) with a standard protocol $\left(95^{\circ} \mathrm{C}, 20 \mathrm{~s} ; 45\right.$ cycles of $95^{\circ} \mathrm{C}, 3 \mathrm{~s}$ and $60^{\circ} \mathrm{C}, 30 \mathrm{~s}$ ). For relative quantification the ddCT method was used. Values of CaBP$9 \mathrm{k}$ and VDR were normalized against the house keeping gene beta-actin.

Quantitative RT-PCR of the housekeeping gene glyceraldehyde 3-phosphate dehydrogenase (GAPDH), the transient receptor potential vanilloid type 5/6 channels (TRPV5/6), calbindin-D28K (CaBP-28k), intestinal plasma calcium ATPase (PMCA1b), renal $\mathrm{Na} / \mathrm{Ca}$ exchanger (NCX) and renal 1a-hydroxylase was done as described for goat samples earlier (Wilkens et al., 2012, Herm et al., 2015). Copy numbers of TRPV5/6, CaBP-28k, PMCA1b and NCX were calculated using standard curves and normalized to the expression of the house keeping gene GAPDH.

\subsubsection{Western blot analysis}

Protein extraction and Western blot analysis of VDR and CaBP-28k were carried out as described by Kovács et al. (2015). As primary antibody, monoclonal antibodies against VDR (Abcam, Cambridge, UK, diluted 1:200 in TBST) or CaBP-28k (Swant, Bellinzona, Switzerland, diluted 1:500 in TBST), respectively, were used. As secondary antibody a horseradish peroxidase (HRP)-conjugated goat anti-rat antibody (Sigma-Aldrich, St. Louis, USA, diluted 1:10,000 in TBST/2.5\% fat-free milk) was used for detection of VDR. In case of CaBP-28k a peroxidase-conjugated antimouse antibody (Sigma-Aldrich, St. Louis, USA, diluted 1:20,000 in TBST/2.5\% fatfree milk) was applied. Detection was achieved using enhanced chemiluminescence (Super Signal West Femto Maximum Sensitivity Substrate; Socochim, Lausanne, Switzerland) and a ChemiDoc system (Bio Rad, Cressier, Switzerland). The protein expression of VDR and CaBP-28k were normalized to the amount of GAPDH determined by means of a monoclonal antibody against GAPDH (Sigma-Aldrich, St. Louis, USA, diluted 1:30,000 in TBST) and a peroxidase-conjugated anti-mouse antibody (Sigma-Aldrich, St. Louis, USA, diluted 1:40,000 in TBST/2.5\% fat-free milk). Quantities were calculated as the ratio of VDR or CaPB-28k to GAPDH. Protein extraction and Western blot analysis of TRPV5/6, PMCA and CaBP-9k were 
done as already described before for sheep and goat tissues (Schröder et al., 2001; Wilkens et al., 2011; Wilkens et al., 2012; Herm et al., 2015).

\subsubsection{Peripheral quantitative computed tomographie (pQCT)}

Bone mineral density (BMD) and bone mineral content (BMC) were measured by peripheral quantitative computed tomography on $\mathrm{d} 0,7$ and 13 with Stratec XCT 960A (Stratec Medizintechnik GmbH, Pforzheim, Germany). The goats were placed in a lateral position on an examination table and the left metatarsus was held in the $\mathrm{CT}$ tube by a plexiglas tube. The length was defined as the distance between dewclaw and calcaneus. The densitometry was taken at two positions, at $10 \%$ and $50 \%$ of the overall length. After slaughtering, the left metatarsus was removed, freed of soft tissue and bone density was measured at the $50 \%$ and $10 \%$ positions of the total length.

\subsubsection{Statistical analysis}

All results are presented as mean \pm SEM. To test the difference of time-dependent patterns of plasma parameters and renal excretion analysis of variance for repeated measurements (RM ANOVA) followed by Bonferroni post-test were conducted. Comparison of results of $\mathrm{Ca}$ flux rates, RNA and protein expression was carried out by one-way ANOVA followed by post-testing for linear trends.

Level of significance was set at a value of $P<0.05$. All tests were performed by GraphPad Prism Version 6.00 (GraphPad Software, San Diego, California, USA). 


\subsection{Results}

\subsubsection{Feed intake and live weight changes}

Mean intake of nutrients and minerals is presented in Table 1. The average body weight of the growing goats was $19.2 \pm 2.5 \mathrm{~kg}$ at the beginning of the trial, increased continuously during the trial, and was $21.1 \pm 2.5 \mathrm{~kg}$ at the end (Table 2).

\subsubsection{Serum concentrations of minerals}

Serum concentrations of macrominerals are depicted in Fig. 1.

During the entire observation period, mean serum $\mathrm{Ca}$ concentrations of all groups remained within the physiological range for adult goats $(2.2 \mathrm{mM}-2.7 \mathrm{mM}$ [Tschuor et al., 2008]). Slight alterations over time could be observed $(P=0.0018)$.

Serum $\mathrm{P}$ concentrations of both treatment groups were significantly altered in a dosedependent manner $(P<0.0001)$. Beginning with day 4 , serum concentrations of $P$ determined for group Z1.6 decreased below the reference value of $1.2 \mathrm{mM}$ (Tschuor et al., 2008).

A significant decline due to the supplementation with zeolite could also been shown for serum concentrations of $\mathrm{Mg}$ (effect of time: $P<0.0001$, effect of treatment: $P=$ $0.0034)$.

\subsubsection{Urinary $\mathrm{pH}$ and renal excretion of $\mathrm{Ca}, \mathrm{P}$ and $\mathrm{Mg}$}

Urinary $\mathrm{pH}$ ranged between 8.271 and 8.443 and was not affected by treatment. Ratios of respective minerals normalized to Creat are presented in Fig. 2. While $\mathrm{Ca}$ excretion was slightly increased by zeolite supplementation $(P=0.0195)$, renal excretion of $P$ was significantly reduced in both treatment groups $(P=0.0177)$.

\subsubsection{Serum concentrations of vitamin D metabolites}

While circulating concentrations of 25-OHD were not significantly affected by the treatment, serum concentrations of 1,25-(OH)2D decreased in group Z1.6 during the observation period (Fig. 3) (effect of time: $P=0.0007$, effect of treatment: $P=$ 0.0047). 
Table 1. Mean daily intakes (hay and concentrate) of nutrients and minerals

\begin{tabular}{|c|c|c|c|c|}
\hline & Control $^{1}$ & $\mathrm{Z1.2^{2 }}$ & $\mathrm{Z1.6^{3 }}$ & Pooled SEM \\
\hline \multicolumn{5}{|l|}{ Week 1: } \\
\hline Dry matter intake, $\mathrm{g}$ & 630 & 631 & 649 & 22.5 \\
\hline $\mathrm{ME}, \mathrm{MJ}$ & 4.28 & 4.30 & 4.40 & 0.15 \\
\hline Crude protein, $\mathrm{g}$ & 125 & 126 & 129 & 4.33 \\
\hline $\mathrm{ADF}^{\dagger}, \mathrm{g}$ & 143 & 143 & 148 & 5.56 \\
\hline $\mathrm{NDF}^{\dagger}, \mathrm{g}$ & 247 & 247 & 255 & 9.40 \\
\hline Calcium, g & 7.41 & 7.43 & 7.63 & 0.26 \\
\hline Phosphorus, g & 2.94 & 2.96 & 3.03 & 0.10 \\
\hline Magnesium, g & 1.82 & 1.83 & 1.87 & 0.06 \\
\hline \multicolumn{5}{|l|}{ Week 2: } \\
\hline Dry matter intake, g & 614 & 635 & 661 & 26.5 \\
\hline ME, MJ & 4.13 & 4.33 & 4.46 & 0.18 \\
\hline Crude protein, $\mathrm{g}$ & 121 & 127 & 131 & 5.38 \\
\hline $\mathrm{ADF}^{\dagger}, \mathrm{g}$ & 142 & 143 & 152 & 6.56 \\
\hline $\mathrm{NDF}^{\dagger}, \mathrm{g}$ & 244 & 247 & 262 & 11.0 \\
\hline Calcium, g & 7.21 & 7.48 & 7.77 & 0.31 \\
\hline Phosphorus, g & 2.84 & 2.98 & 3.07 & 0.13 \\
\hline Magnesium, g & 1.76 & 1.84 & 1.90 & 0.08 \\
\hline \multicolumn{5}{|l|}{ Week 3: } \\
\hline Dry matter intake, g & 699 & 664 & 695 & 34.8 \\
\hline ME, MJ & 4.65 & 4.50 & 4.59 & 0.25 \\
\hline Crude protein, $\mathrm{g}$ & 136 & 132 & 134 & 7.46 \\
\hline $\mathrm{ADF}^{\dagger}, \mathrm{g}$ & 165 & 151 & 166 & 8.37 \\
\hline $\mathrm{NDF}^{\dagger}, \mathrm{g}$ & 283 & 261 & 283 & 14.1 \\
\hline Calcium, g & 8.19 & 7.81 & 8.13 & 0.41 \\
\hline Phosphorus, g & 3.20 & 3.10 & 3.16 & 0.17 \\
\hline Magnesium, g & 2.00 & 1.92 & 1.98 & 0.10 \\
\hline \multicolumn{5}{|c|}{${ }^{\dagger}$ Contents of ADF and NDF were calculated from crude fibre (CF) according to the following } \\
\hline \multicolumn{5}{|c|}{ equations: $A D F[\mathrm{~g} / \mathrm{kg} \mathrm{DM}]=1.14 \cdot \mathrm{CF}[\mathrm{g} / \mathrm{kg} \mathrm{DM}]+42.2 ; \mathrm{NDF}[\mathrm{g} / \mathrm{kg} \mathrm{DM}]=1.58 \mathrm{CF}[\mathrm{g} / \mathrm{kg} \mathrm{DM}$} \\
\hline \multicolumn{5}{|c|}{ + 135.7 (Kamphues et al., 2014). } \\
\hline \multicolumn{5}{|c|}{${ }^{1}$ Contol $=$ control group $(n=5)$} \\
\hline \multicolumn{5}{|c|}{${ }^{2} \mathrm{Z} 1.2$ = supplemented with $1.2 \mathrm{~g}$ zeolite/kg BW $(n=6)$} \\
\hline${ }^{3} Z 1.6=$ supplemente & g zeolite & 6) & & \\
\hline
\end{tabular}


Table 2. Mean body weight $[\mathrm{kg}]$ of goats for three weeks beginning at an age of eleven weeks

\begin{tabular}{ccccc}
\hline Day $^{\mathbf{1}}$ & Control $^{2}$ & $\mathbf{Z 1 . 2}^{3}$ & $\mathbf{Z 1 . 6}^{\mathbf{4}}$ & Pooled SEM \\
\hline 0 & 19.2 & 19.3 & 19.3 & 0.595 \\
4 & 19.4 & 20.1 & 20.5 & 0.636 \\
8 & 19.9 & 20.2 & 21.0 & 0.584 \\
12 & 19.8 & 20.0 & 20.7 & 0.563 \\
16 & 20.8 & 21.2 & 21.3 & 0.572 \\
21 & 21.2 & 20.8 & 21.4 & 0.597 \\
${ }^{1}$ Day = day on treatment & & \\
${ }^{2}$ Contol = control group (n=5) & & \\
${ }^{3} Z 1.2=$ supplemented with 1.2 g zeolite/kg BW $(\mathrm{n}=6)$ & \\
${ }^{4} Z 1.6=$ supplemented with 1.6 g zeolite/kg BW $(\mathrm{n}=6)$ &
\end{tabular}

\subsubsection{Analysis of bone parameters: Serum concentrations of SCL and $O C ; B M D, B M C$}

During the observation period, SCL and OC showed opposing trends resulting in a significant influence of the treatment on the ratio of bone formation to bone resorption (Fig. 4) $(P=0.0498)$. No differences in BMD or BMC were observed (Table 3)

\subsubsection{Ussing chamber experiments}

In $\mathrm{RU}, \mathrm{J}_{\mathrm{ms}}$ of $\mathrm{Ca}$ exceeded $\mathrm{J}_{\mathrm{sm}}$. The resulting positive $\mathrm{J}_{\text {net }}$ indicating net absorption was not significantly influenced by the experimental diets. Mean values amounted to $1.9 \pm 0.2 \mathrm{nmol} /(\mathrm{cm} 2 \cdot \mathrm{h})$ in the control group, $7.3 \pm 2.6 \mathrm{nmol} /(\mathrm{cm} 2 \cdot \mathrm{h})$ in group Z1.2, and $3.9 \pm 1.4 \mathrm{nmol} /(\mathrm{cm} 2 \cdot \mathrm{h})$ in group Z1.6.

In DD, $J_{s m}$ exceeded $J_{m s}$, resulting in a negative $J_{\text {net }}$ indicating a net secretion of $\mathrm{Ca}$ that was not affected by the diet. Mean values amounted to $-8.7 \pm 2.1 \mathrm{nmol} /(\mathrm{cm} 2 \mathrm{~h})$ in the control group, $-12.4 \pm 3.2 \mathrm{nmol} /(\mathrm{cm} 2 \mathrm{~h})$ in group $\mathrm{Z1.2}$ and $-9.4 \pm 2.2 \mathrm{nmol} /(\mathrm{cm} 2$ h) in group Z1.6. 

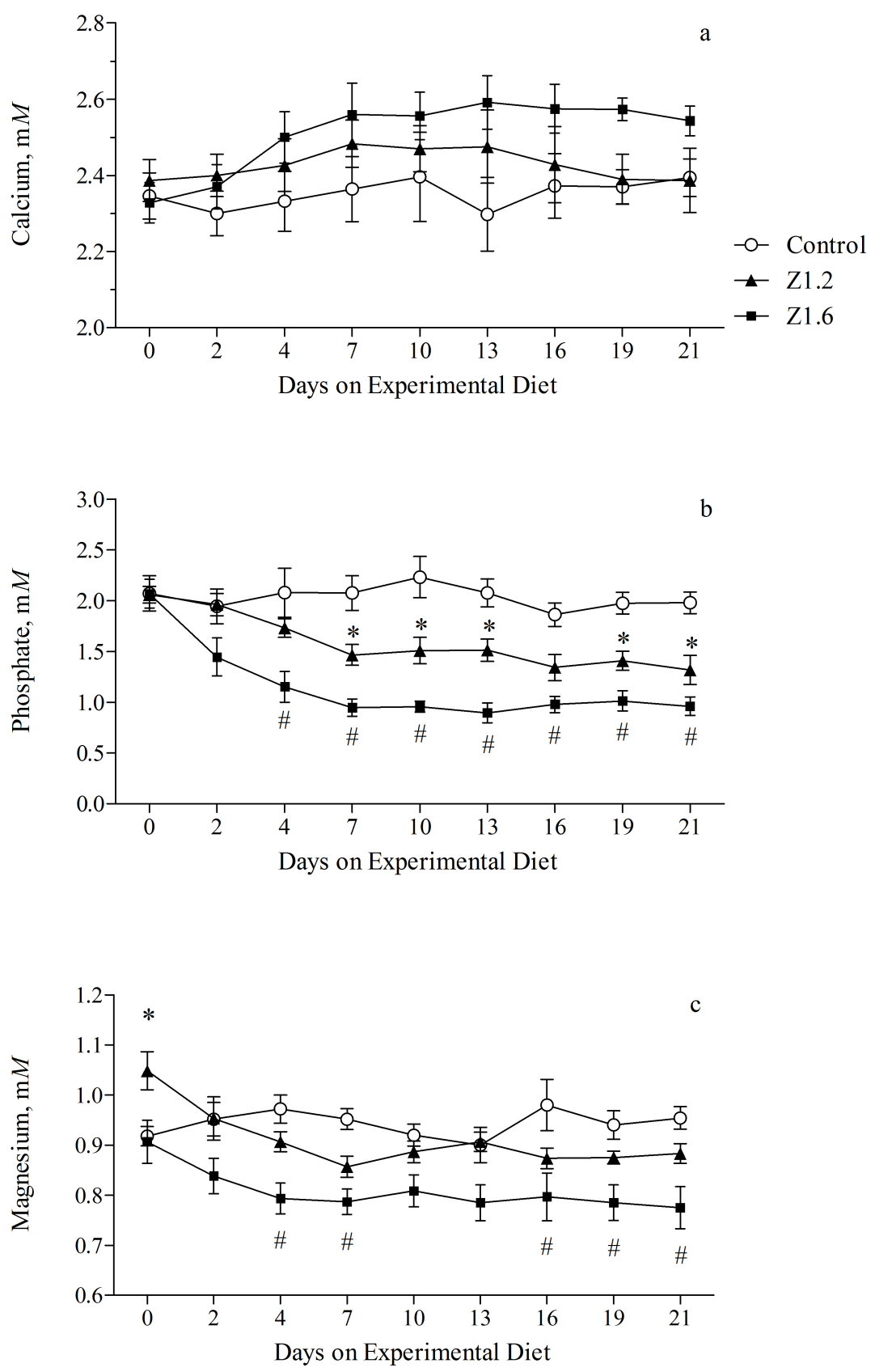

Figure 1. Serum concentrations of calcium (a), phosphate (b) and magnesium (c) of growing goats belonging to the control group (Control, $n=5$ ) or supplemented with zeolite in a dosage of $1.2 \mathrm{~g} / \mathrm{kg} \mathrm{BW}(Z 1.2, \mathrm{n}=6)$ or $1.6 \mathrm{~g} / \mathrm{kg} \mathrm{BW}(Z 1.6, \mathrm{n}=6)$. Data are given as means \pm SEM. Analysis of variance for repeated measurements revealed an effect of time on calcium $(P<0.01)$ and effects of time, supplementation and an interaction of both factors on phosphate $(P<0.001, P<0.001, P<0.001)$ and magnesium $(P<0.001, P<0.01, P<$ 0.001). Differences revealed for the respective time point by Bonferroni post-test between control and Z1.2 or between control and Z1.6 are indicated by * (Z.1.2) and \# (Z1.6). 

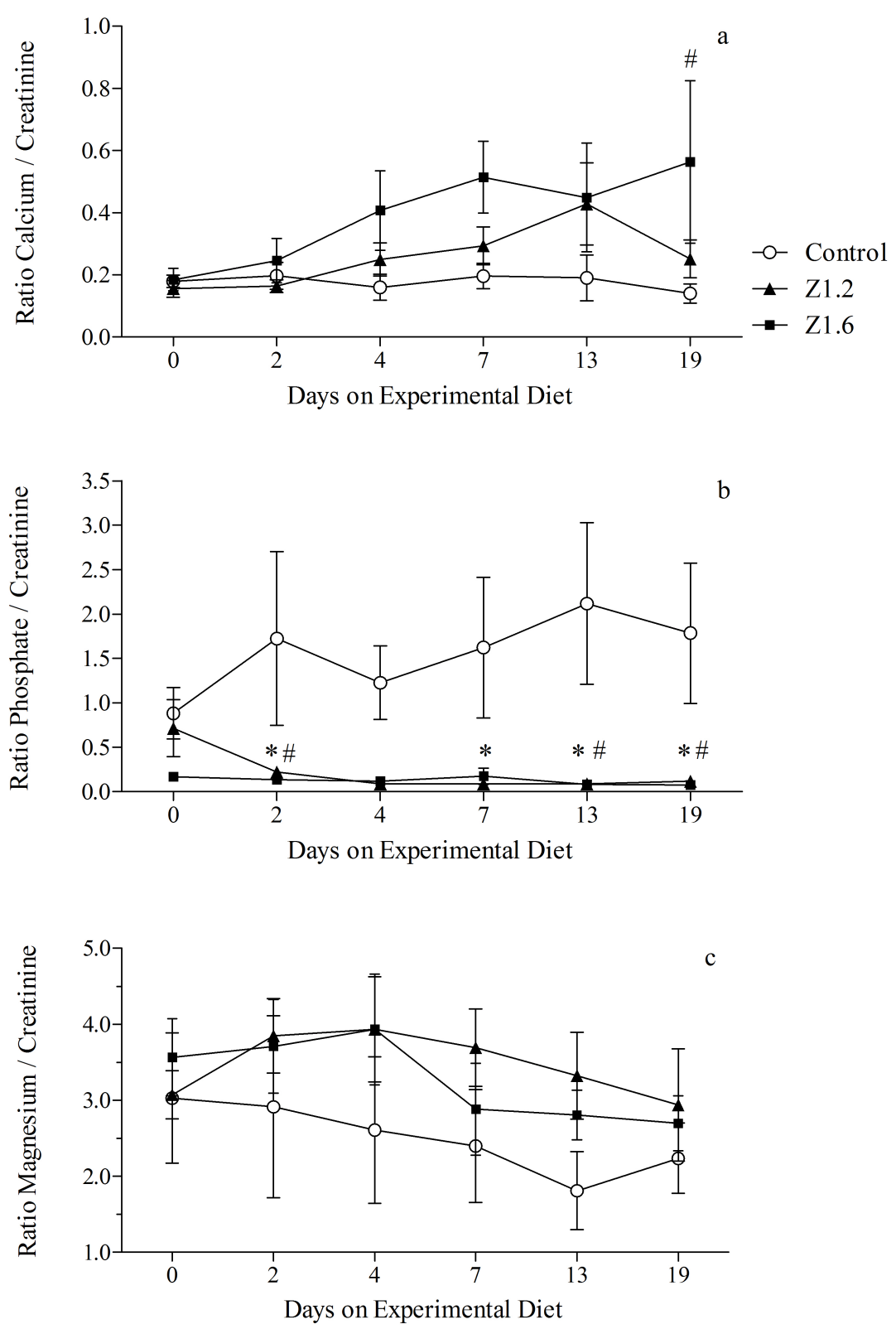

Figure 2. Urinary excretion of calcium (a), phosphate (b) and magnesium (c) of growing goats belonging to the control group (Control, $n=5$ ) or supplemented with zeolite in a dosage of $1.2 \mathrm{~g} / \mathrm{kg} \mathrm{BW}(Z 1.2, \mathrm{n}=6)$ or $1.6 \mathrm{~g} / \mathrm{kg} \mathrm{BW}(Z 1.6, \mathrm{n}=6)$. Data are given as means \pm SEM. Analysis of variance for repeated measurements revealed an effect of the supplementation on urinary calcium $(P<0.05)$, an effect of the supplementation and an interaction of time and the supplementation on urinary phosphate $(P<0.05, P<0.05)$ and an effect of time on magnesium excretion $(P<0.05)$. Differences revealed for the respective time point by Bonferroni post-test between control and Z1.2 or between control and Z1.6 are indicated by * (Z.1.2) and \# (Z1.6). 

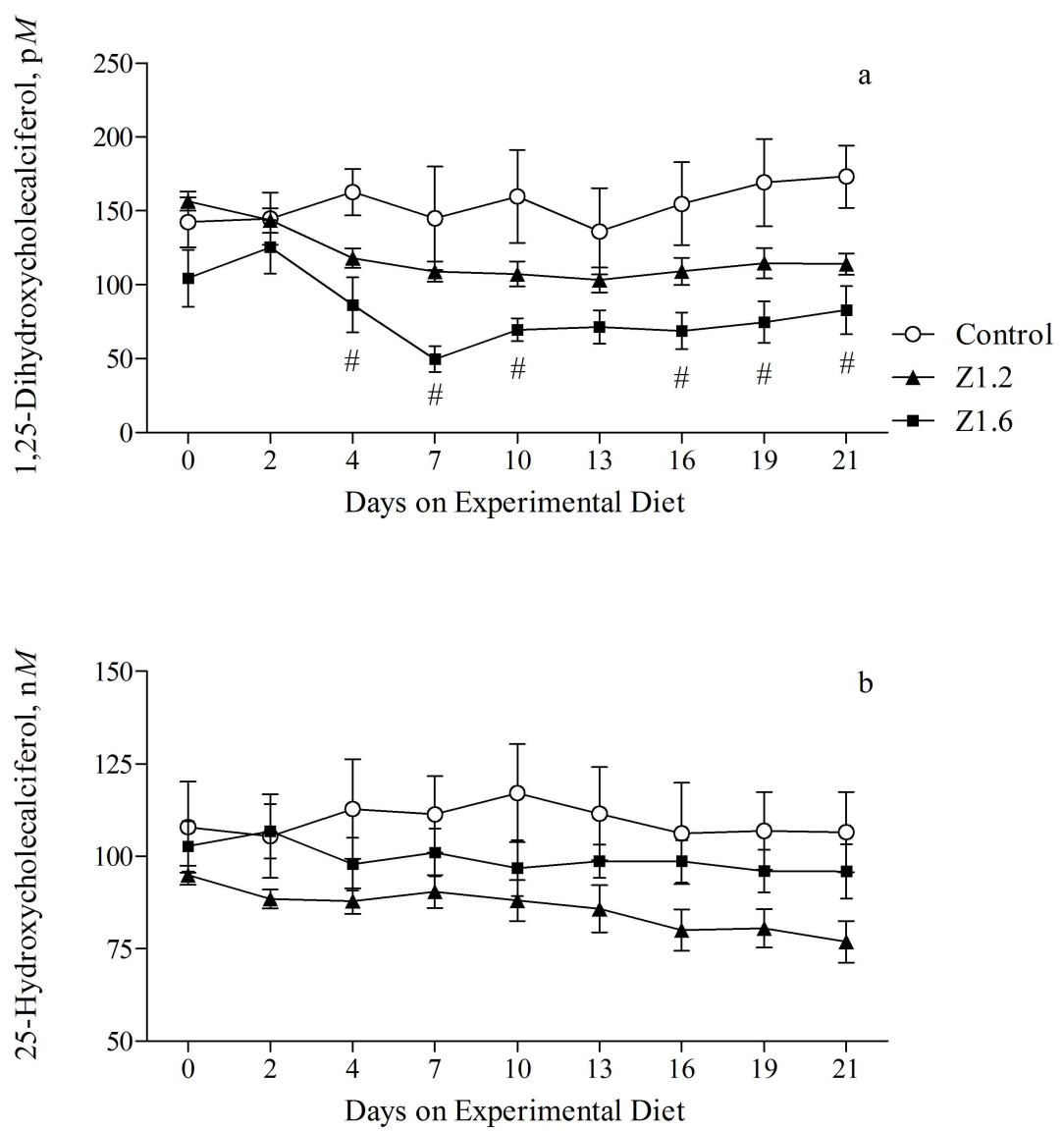

Figure 3. Serum concentrations of 1,25-dihydroxycholecalciferol (a) and 25hydroxycholecalciferol (b) of growing goats belonging to the control group (Control, $n=5$ ) or supplemented with zeolite in a dosage of $1.2 \mathrm{~g} / \mathrm{kg} \mathrm{BW}(Z 1.2, \mathrm{n}=6)$ or $1.6 \mathrm{~g} / \mathrm{kg} \mathrm{BW}(Z 1.6, \mathrm{n}=$ 6). Data are given as means \pm SEM. Analysis of variance for repeated measurements revealed effects of time, supplementation and an interaction of both factors $(P<0.001, P<$ $0.01, P<0.05)$ on 1,25-dihydroxycholecalciferil, while a significant effect of time $(P<0.001)$ as well as a trend for an interaction $(P=0.06)$ could be shown for 25 -hydroxycholecalciferol. Differences revealed for the respective time point by Bonferroni post-test between control and Z1.6 are indicated by \#. 
Table 3. Weekly measurements of bone mineral content and bone mineral density of the left metatarsus of goats beginning at an age of eleven weeks

\begin{tabular}{|c|c|c|c|c|c|}
\hline & Day $^{1}$ & Control $^{2}$ & $\mathrm{Z1.2}^{3}$ & $\mathbf{Z 1 . 6}^{4}$ & Pooled SEM \\
\hline \multirow{4}{*}{$\begin{array}{l}\text { Total distal content, } \\
\mathrm{mg} / \mathrm{cm}\end{array}$} & 0 & 130 & 149 & 149 & 25.6 \\
\hline & 7 & 150 & 130 & 139 & 24.9 \\
\hline & 13 & 160 & 142 & 148 & 27.4 \\
\hline & 21 & 136 & 131 & 141 & 33.7 \\
\hline \multirow{4}{*}{$\begin{array}{l}\text { Total distal density, } \\
\mathrm{mg} / \mathrm{cm}^{3}\end{array}$} & 0 & 405 & 422 & 415 & 48.3 \\
\hline & 7 & 409 & 419 & 396 & 40.4 \\
\hline & 13 & 447 & 410 & 403 & 52.5 \\
\hline & 21 & 427 & 397 & 398 & 40.9 \\
\hline \multirow[t]{4}{*}{ Trabecular content } & 0 & 48 & 61 & 58 & 13.0 \\
\hline & 7 & 60 & 48 & 53 & 14.4 \\
\hline & 13 & 63 & 55 & 57 & 16.1 \\
\hline & 21 & 59 & 58 & 62 & 16.7 \\
\hline \multirow[t]{4}{*}{ Trabecular density } & 0 & 328 & 378 & 356 & 60.1 \\
\hline & 7 & 358 & 338 & 329 & 69.2 \\
\hline & 13 & 396 & 340 & 347 & 85.6 \\
\hline & 21 & 396 & 393 & 391 & 55.9 \\
\hline \multirow[t]{4}{*}{ Total medial content } & 0 & 87 & 98 & 97 & 11.2 \\
\hline & 7 & 87 & 101 & 101 & 10.0 \\
\hline & 13 & 90 & 105 & 98 & 10.3 \\
\hline & 21 & 88 & 93 & 93 & 9.2 \\
\hline \multirow[t]{4}{*}{ Total medial density } & 0 & 645 & 637 & 651 & 67.4 \\
\hline & 7 & 636 & 684 & 697 & 58.3 \\
\hline & 13 & 664 & 646 & 665 & 67.8 \\
\hline & 21 & 677 & 617 & 647 & 50.2 \\
\hline \multirow[t]{4}{*}{ Cortical content } & 0 & 82 & 92 & 92 & 11.4 \\
\hline & 7 & 82 & 96 & 97 & 9.9 \\
\hline & 13 & 85 & 98 & 94 & 10.2 \\
\hline & 21 & 84 & 88 & 89 & 7.6 \\
\hline \multirow[t]{4}{*}{ Cortical density } & 0 & 887 & 882 & 901 & 54.2 \\
\hline & 7 & 883 & 911 & 954 & 44.6 \\
\hline & 13 & 915 & 891 & 937 & 52.0 \\
\hline & 21 & 966 & 941 & 963 & 25.4 \\
\hline
\end{tabular}

${ }^{1}$ Day $=$ day on treatment

${ }^{2}$ Contol $=$ control group $(\mathrm{n}=5)$

${ }^{3} \mathrm{Z} 1.2$ = supplemented with $1.2 \mathrm{~g}$ zeolite $/ \mathrm{kg} \mathrm{BW}(\mathrm{n}=6)$

${ }^{4} \mathrm{Z} 1.6$ = supplemented with $1.6 \mathrm{~g}$ zeolite/kg BW $(n=6)$

For total medial and cortical content, ANOVA followed by Tukey'post-test revealed a significant effect of the experimental group (Control vs. Z1.2: $P<0.05$ ), while an effect of time was revealed for cortical density (day 0 vs. day 21 : $P<0.01$ ). 

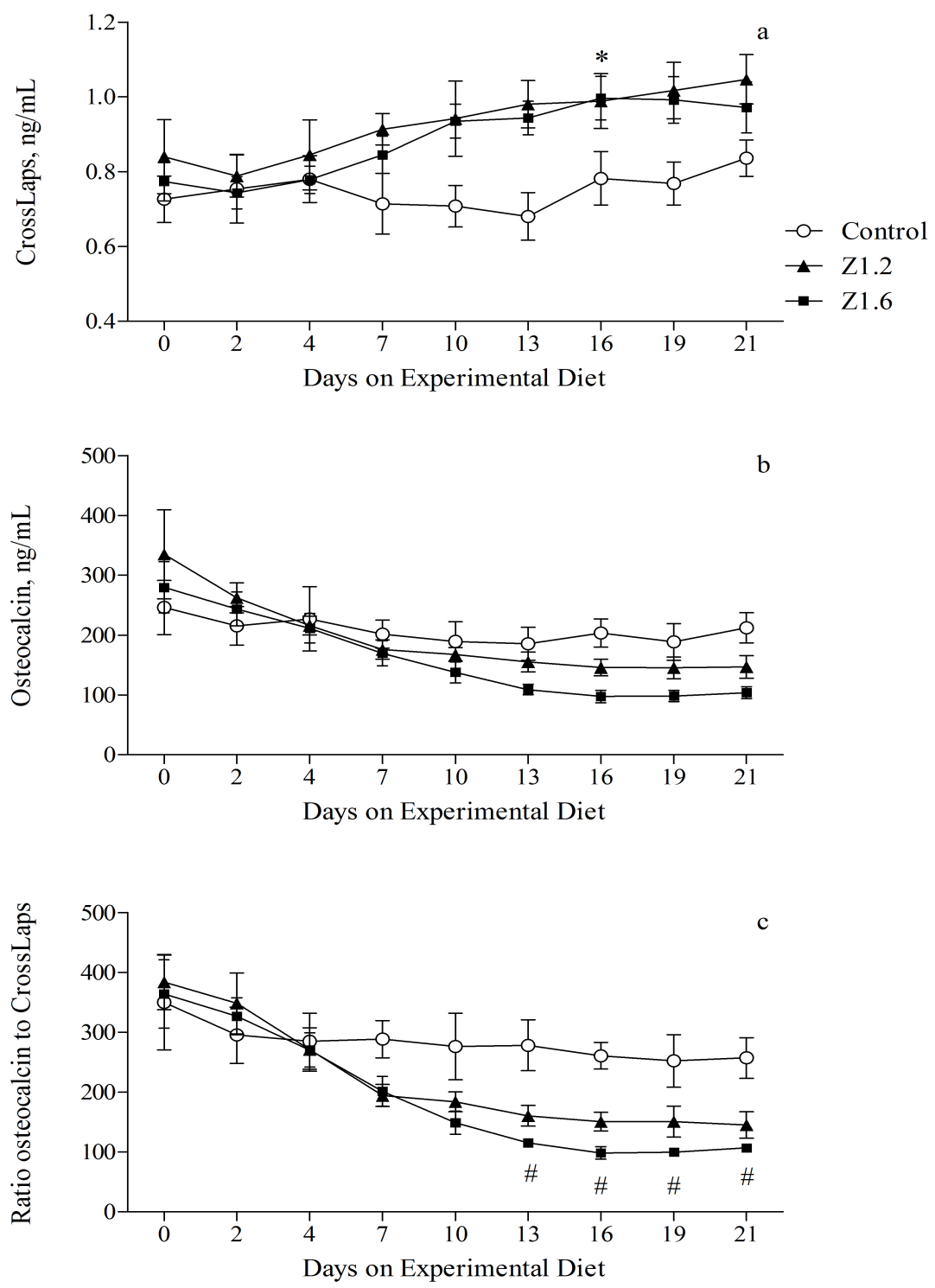

Figure 4. Serum concentrations of the bone resorption marker CrossLaps (a), the bone formation marker osteocalcin (b) and the ratio of osteocalcin to CrossLaps (c) of growing goats belonging to the control group (Control, $n=5$ ) or supplemented with zeolite in a dosage of $1.2 \mathrm{~g} / \mathrm{kg} \mathrm{BW}(Z 1.2, \mathrm{n}=6)$ or $1.6 \mathrm{~g} / \mathrm{kg} \mathrm{BW}(Z 1.6, \mathrm{n}=6)$. Data are given as means \pm SEM. Analysis of variance for repeated measurements revealed effects of time and an interaction of time and the supplementation on CrossLaps $(P<0.001, P<0.05)$ and on osteocalcin $(P<0.001, P<0.05)$, while effects of time, the supplementation and an interaction of both factors $(P<0.001, P<0.05, P<0.01)$ could be shown for the ratio of the both bone markers. Differences revealed for the respective time point by Bonferroni post-test between control and Z1.2 or between control and Z1.6 are indicated by * (Z.1.2) and \# (Z1.6). 


\subsubsection{Expression of VDR, 1a-hydroxylase and structures involved in transcellular Ca transport}

Data on duodenal expression are given in Fig. 5. No effects could be found for RNA expression of VDR and PMCA, while RNA expression of TRPV6 and CaBP-9k showed a trend for reduction with the zeolite supplementation $(P=0.0975, P=$ $0.0443)$. Protein expression decreased by the treatment for CaBP-9k $(P=0.657)$ and showed no differences for VDR or PMCA. Examples of Western blots are given in Fig. 6.

In renal tissues, RNA expression of TRPV5, CaBP-28k and NCX1 as well as protein expression of CaBP-28k were increased by the treatment $(P=0.0692, P=0.0455, P$ $=0.0029, P=0.0004)$, while expression of VDR and 1 $\alpha$-hydroxylase was not altered (Fig. 7). 

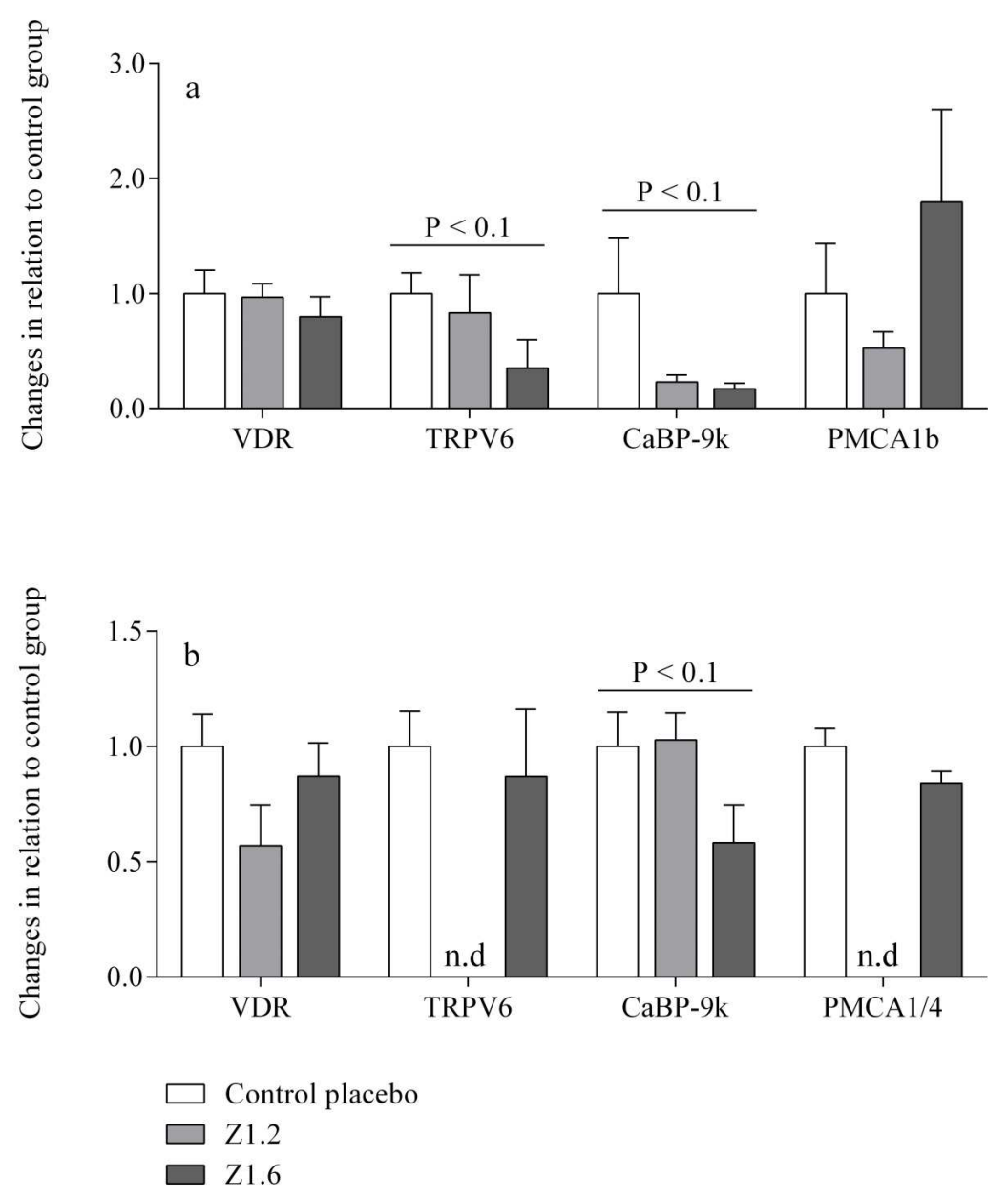

Figure 5. Effects of the supplementation of zeolite in a dosage of $1.2 \mathrm{~g} / \mathrm{kg} \mathrm{BW}(Z 1.2, \mathrm{n}=6)$ or $1.6 \mathrm{~g} / \mathrm{kg} \mathrm{BW}(\mathrm{Z1.6}, \mathrm{n}=6$ ) on RNA (a) and protein expression (b) of vitamin D receptor (VDR), the epithelial calcium channels transient receptor potential vanilloid type 6 (TRPV6), calbindin- $\mathrm{D}_{9 \mathrm{~K}}(\mathrm{CaBP}-9 \mathrm{k})$ and plasma membrane Ca-ATPase (PMCA1/4) in the duodenum of growing goats expressed as means \pm SEM in relation to the control group. Results of one way analysis of variance followed by post-testing for are linear trends are given within the figures; n.d.: not determined. 


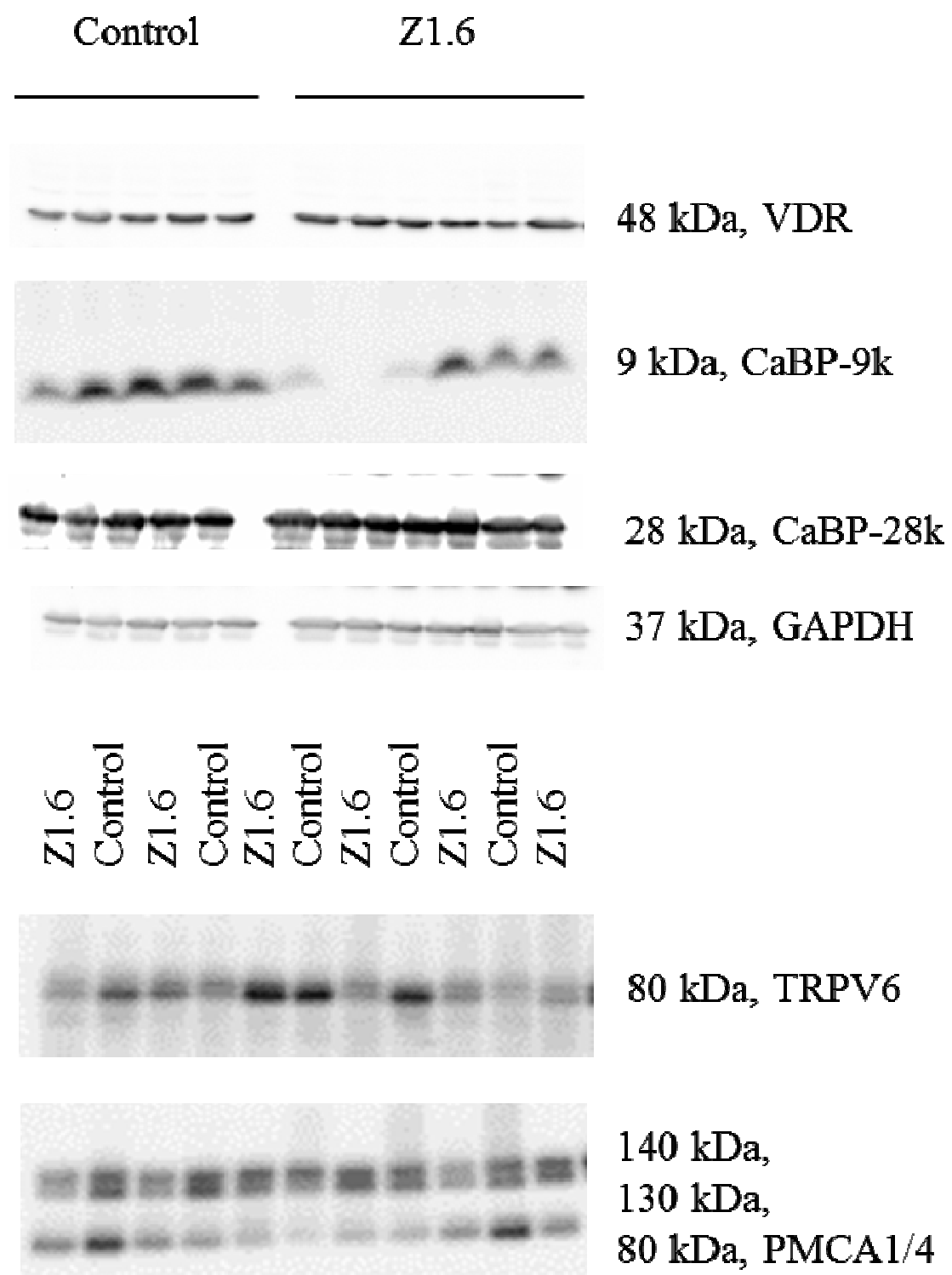

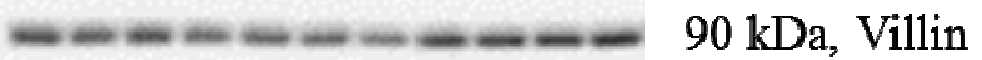

Figure 6. Representative Western blot results of vitamin $D$ receptor (VDR), calbindin- $D_{9 k}$ (CaBP-9k), calbindin- $\mathrm{D}_{28 \mathrm{k}}$ (CaBP-28k), the housekeeping gene glyceraldehyde 3-phosphate dehydrogenase (GAPDH), transient receptor potential vanilloid type 6 (TRPV6), plasma membrane Ca-ATPase (PMCA1/4) and the housekeeping gen villin. Sample tissues derived from goats belonging to the control group (Control, $n=5$ ) or supplemented with zeolite in a dosage of $1.6 \mathrm{~g} / \mathrm{kg} \mathrm{BW}(Z 1.6, \mathrm{n}=6)$. 

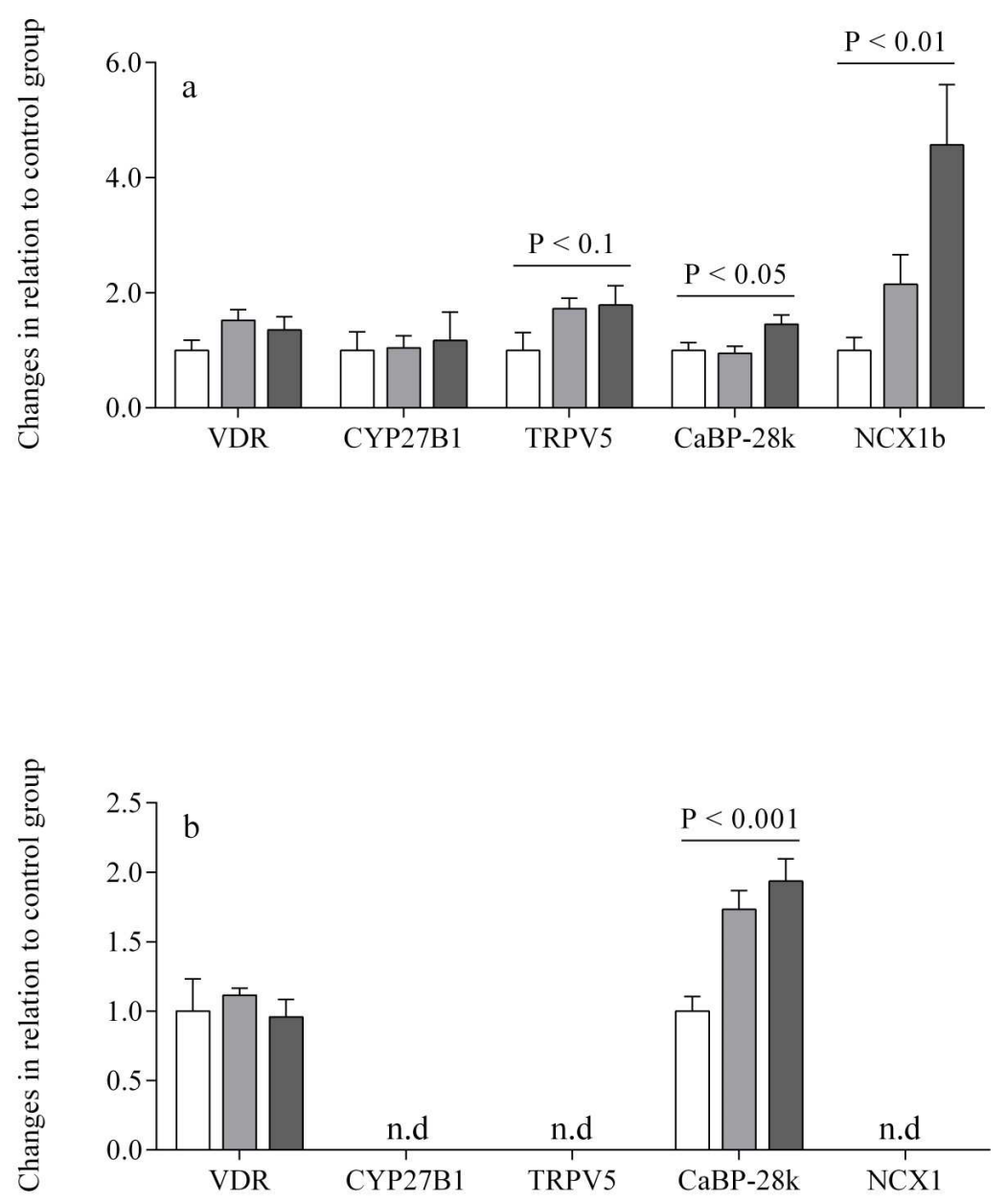

Figure 7. Effects of the supplementation of zeolite in a dosage of $1.2 \mathrm{~g} / \mathrm{kg} \mathrm{BW}(Z 1.2, \mathrm{n}=6)$ or $1.6 \mathrm{~g} / \mathrm{kg} \mathrm{BW}(\mathrm{Z1.6}, \mathrm{n}=6$ ) on RNA (a) and protein expression (b) of vitamin D receptor (VDR), 1 $\alpha$-hydroxylase (CYP27B1), the epithelial calcium channels transient receptor potential vanilloid type 5 (TRPV5), calbindin- $\mathrm{D}_{28 \mathrm{~K}}$ (CaBP-28k) and the sodium calcium exchanger type 1 (NCX1) in the kidney of growing goats expressed as means \pm SEM in relation to the control group. Results of one way analysis of variance are given within the figures; n.d.: not determined. 


\subsection{Discussion}

Goat kids of group Z1.6 showed a slight increase in mean serum Ca concentrations compared with the control group. However, neither an elevation of 1,25-(OH)2D3 nor an elevation of active gastrointestinal absorption was detected. This confirms hypothesis 3 , which assumed a stimulated $\mathrm{Ca}$ mobilization, but rejects hypothesis 2 , which assumed an involvement of 1,25-(OH)2D3.

In an in-vitro study, Thilsing et al. (2006) showed that zeolite might bind $\mathrm{Ca}$ in the rumen, but could release it again in the abomasum. Perhaps the capacity of zeolite to bind $\mathrm{Ca}$ in the rumen, especially in combination with the above mentioned release, might be too small to have a relevant effect on the $\mathrm{Ca}$ homeostasis of the goats. In fact, the binding capacity of zeolite to $\mathrm{P}$ seems to be more effective. In the acidic $\mathrm{pH}$ in the abomasum, zeolite A breaks down and silicic acid, aluminium and amorphous aluminium silicates are set free (Cook et al., 1982). Aluminium ions are able to form tight complexes with $\mathrm{P}$ (Allen, 1984). These complexes remain insoluble and therefore indigestible throughout the rest of the gastrointestinal tract, while $\mathrm{Ca}$ is released in the abomasum and available in the intestine. This is in accordance to several in vivo experiments, where a significant decrease in serum $\mathrm{P}$ concentrations during zeolite administration has been reported (Enemark et al., 2003; Pallesen et al., 2008). In humans, several products like calcium acetate, lanthanum carbonate or sevelamer carbonate are known to bind phosphate and are used as therapeutics, for example in chronic kidney diseases. Phosphorus binders significantly lower serum und urine $P$ concentrations during their application (Block et al. 2012).

Low concentrations of $P$ are discussed to be responsible for the elevation of mean $\mathrm{Ca}$ concentrations in the blood. A significant reduction in serum $\mathrm{P}$ was observed in both treatment groups. In several studies with sheep (Maunder et al., 1986; Scott et al., 1997), goats (Schröder et al., 1995) and cattle (Kichura et al., 1982; Barton et al., 1987 ) it has been reported that diets low in $\mathrm{P}$ lead to an increase in $\mathrm{Ca}$ concentrations in blood. In contrast to monogastric animals, this increase happens without any change in circulating concentrations of 1,25-(OH)2D3 (Schröder et al., 1995; Scott et al., 1997). There is evidence for increased binding affinity of intestinal VDR receptors to 1,25-(OH)2D3 in P-depleted lactating goats (Schröder et al., 1990). For growing goats, a comparable impact could not be shown (Schröder et al., 1995). 
In addition, the effect on intestinal VDR seems unlikely because neither elevated active $\mathrm{Ca}$ absorption in the treatment groups determined by Ussing chamber technique nor changes in intestinal RNA and protein expression of $\mathrm{Ca}$ transporters could be observed.

In fact, in ruminants reduced $\mathrm{P}$ intake may cause a rise in bone resorption without involvement of 1,25-(OH)2D3 (Scott et al., 1997). The exact mechanisms mediating this phenomenon are still unknown, but a lack of $P$ for creating hydroxyapatite crystals is suggested. The changes in the ratio of SCL to OC in the treatment groups indicate elevated bone resorption together with reduced bone formation in these groups. Osteocalcin is known to decrease physiologically with age (Corlett et al., 1990). However, because of stable values in the control group, increased maturity does not seem to be the reason for the decreased $O C$ concentrations during that time in the present study. Bone resorption was uncoupled from bone formation and overbalanced in the treatment groups. However, there were no differences in BMD and BMC. Possibly the length of the trial was too short for apparent changes in bone structure.

In addition to low $\mathrm{P}$ concentrations, reduced dietary $\mathrm{Mg}$ intake is also known to alter bone structure. In both treatment groups, a significant reduction of $\mathrm{Mg}$ concentrations in serum over time was evident. In accordance with these findings, Enemark et al. (2003) presented significantly lower Mg concentrations in serum of treated dry cows compared with control group. Furthermore Thilsing et al. (2006) showed in an in vitro study, a zeolite-induced reduction of $\mathrm{Mg}$ in supernatants of rumen fluid. On the contrary, Pallesen et al. (2008) observed no differences of serum Mg concentrations during zeolite application.

Rats fed diets restricted in $\mathrm{Mg}$ showed decreased 1,25-(OH)2D3 concentrations, decreased bone volume, decreased trabecular thickness and increased numbers of osteoclasts compared to control animals (Rude, 2008). In the present study reduced $1,25-(\mathrm{OH}) 2 \mathrm{D} 3$ concentrations in group $\mathrm{Z1.6}$ and a reduced ratio of bone formation to bone resorption were evident. The effect of zeolite $A$ on bone remodeling could be a combination of both pathways, reduced $\mathrm{P}$ and $\mathrm{Mg}$ intake.

The decrease of 1,25-(OH)2D3 caused by low dietary $\mathrm{Mg}$ intake is explainable by a reduction of secretion and action of PTH through altered phosphoinositol activity and decreased adenylate cyclase activity (Rude, 2008). Furthermore, there is evidence for Mg-dependency of the renal 1a-hydroxylase activity (CYP27B1) (Rude, 2008). An 
effect on enzyme activity rather than on its expression would be in line with our results on CYP27B1 expression. Another explanation for reduced 1,25-(OH)2D3 contents could be a reduction of circulating PTH through low concentrations of $\mathrm{P}$. In rats, dietary induced P deficiency causes a fall of serum PTH concentrations (Rader et al., 1979). Because no suitable assay for caprine PTH is available, the determination of serum PTH concentrations in the present study was not possible.

Active $\mathrm{Ca}$ absorption in the GIT and its renal reabsorption are mediated by at least three steps. Driven by an electrochemical gradient $\mathrm{Ca}$ enters the cell via selective, apically located $\mathrm{Ca}$ channels, the TRPV type 6 mainly in intestines and type 5 mainly in kidneys (Hoenderop et al., 1999; Peng et al., 1999). It is then translocated to the basolateral membrane bound to $\mathrm{Ca}$ binding proteins: CaBP-9k in intestines, CaBP28k in the kidney (Wasserman et al., 1966; Kallfelz et al., 1967). Extrusion of Ca out of intestinal epithelial cells is mediated mainly by an energy dependent Ca efflux pump, the PMCA1b (Ghijsen et al., 1982). In the kidney, extrusion of $\mathrm{Ca}$ is predominantly conducted by NCX1 (Loffing and Kaissling, 2003).

Ussing chamber experiments in absence of any electrochemical gradient revealed active $\mathrm{Ca}$ absorption in the rumen and a secretion of $\mathrm{Ca}$ in the duodenum. This is in accordance with results from former studies in which active $\mathrm{Ca}$ absorption in the duodenum occurred only in goats kept on dietary Ca restriction (Wilkens et al., 2012). In the present study, dietary Ca supply was probably high enough to meet the daily requirements by passive diffusion. The relatively high $\mathrm{Ca}$ intake might also explain why the reduction in expression of TRPV6 and CaBP-9k induced by lower 1,25$(\mathrm{OH}) 2 \mathrm{D} 3$ serum concentration did not negatively affect Ca balance.

Results of renal Ca resorption are contradictory in the present study. Because of significantly higher concentrations of the Ca transport protein CaBP-28k and higher RNA expression of TRPV5 and NCX1, an increased Ca reabsorption and therefore a reduced excretion in urine might be expected. However, a tendency to a higher $\mathrm{Ca}$ excretion in both treatment groups was evident. In an earlier study with zeolite $A$ on dairy cows, higher $\mathrm{Ca}$ excretion in urine was also obvious (Grabherr et al., 2009). It was shown for monogastric animals (Coburn and Massry, 1970) that low concentrations of $\mathrm{P}$ are able to cause increased $\mathrm{Ca}$ excretion in urine. One possible explanation may be a decreased reabsorption of $\mathrm{Ca}$ in kidneys through decreased activity of the parathyroid gland, because low concentrations of $P$ may decrease the concentrations of circulating PTH. However, Herm et al. (2015) were able to show 
that modulations of renal $\mathrm{Ca}$ transport proteins in ruminants differ substantially from results reported for monogastric animals. During dietary Ca restriction $(0.26 \%$ Ca for sheep, $0.22 \% \mathrm{Ca}$ for goats) the animals showed no changes or even a downregulation of the Ca transport proteins TRPV5, CaBP-28k and NCX (Herm et al. 2015). Against the background of this finding, an influence of physiological concentrations of $1,25-(\mathrm{OH}) 2 \mathrm{D} 3$ on Ca reabsorption in the kidney of small ruminants seems unlikely. The reason for the higher RNA expression of CaBP-28k and NCX in the kidneys of group Z1.6 is unclear. It could be speculated that increased $\mathrm{Ca}$ filtration due to greater $\mathrm{Ca}$ plasma concentration would lead to increased $\mathrm{Ca}$ concentrations in the tubular fluid reaching the distal tubules. The Ca concentration in the tubular fluid might be involved in regulating RNA expression of CaBP-28k and NCX. This hypothesis is supported by the existence of so-called calcium responsive elements in the promoter region of the CaBP-28k gene in mice (Arnold and Heintz, 1997). However, in the present study, the increase of RNA expression of CaBP-28k and NCX in kidneys was not as high as it is would be needed to reduce $\mathrm{Ca}$ excretion significantly.

$\mathrm{P}$ excretion in urine of treatment groups was reduced during the present trial. This might be explained by an adaptation of the kidneys to the low serum concentrations of $P$. This increases renal $P$ reabsorption and therefore decreases urinary $P$ excretion, which is in accordance with other studies on zeolite (Enemark et al., 2003; Grabherr et al., 2009).

In the present study, a dose-dependent effect of zeolite was apparent. Serum Mg concentrations were only significantly different in group Z1.6 compared to the control group, while serum concentrations of $P$ declined in a dose-dependent manner. Furthermore, alterations of intestinal and renal RNA and protein expression of $\mathrm{Ca}$ transporting structures showed linear trends with dosage.

Whether $\mathrm{Ca}$ availability in the diet is reduced significantly by zeolite $\mathrm{A}$ has not been answered until now. However, with the findings from the present study reduced $P$ availability is more obvious. In contrast to our expectations, an elevation of 1,25$(\mathrm{OH}) 2 \mathrm{D} 3$ in treatment groups was not shown during application of zeolite A. Therefore, our hypothesis 2 has to be rejected. Neither an increased active $\mathrm{Ca}$ absorption in gastrointestinal tract, nor a reduced $\mathrm{Ca}$ excretion in kidney was shown. However, bone mobilization outweighed bone formation; therefore our hypothesis 3 is partially verified. With the findings of this study new hypotheses can be formulated: 
(1): Zeolite $A$ binds dietary $P$ in abomasum and therefore reduces blood $P$ concentrations. (2) Reduced blood $\mathrm{P}$ concentrations alter bone remodeling rate what (3) increases $\mathrm{Ca}$ concentrations in blood. However, whenever rations with zeolite are designed for ruminants, the effects on 1,25-(OH)2D3, bone metabolism and serum concentrations of $\mathrm{P}$ and $\mathrm{Mg}$, which were shown in the present study, should be considered. 


\subsection{References}

Allen, V. G. 1984. Influence of dietary aluminium on nutrient utilization in ruminants. J. Anim. Sci. 59:836-844.

Arnold, D. B., and N. Heintz. 1997. A calcium responsive element that regulates expression of two calcium binding proteins in Purkinje cells. Proc. Natl. Acad. Sci. USA 94:8842-8847.

Arrigo Y., C. Chaubert, R. Daccord, D. Gagnaux, H. Gerber, D. Guidon, F. Jans, J. Kessler, E. Lehmann, I. Morel, A. Münger, M. Rouel, and Y. Wyss. 1999. Fütterungsempfehlungen und Nährwerttabellen für Wiederkäuer: das grüne Buch. $4^{\text {th }}$ ed (In German). Landwirtschaftliche Lehrmittelzentrale, Zollikofen, Switzerland.

Barton, B. A., N. A. Jorgensen, and H. F. DeLuca. 1987. Impact of prepartum dietary phosphorus intake on calcium homeostasis at parturition. J. Dairy Sci. 70:1186-1191.

Block, G. A., D. C. Wheeler, M. S. Persky, B. Kestenbaum, M. Ketteler, D. M. Spiegel, M. A. Allison, J. Asplin, G. Smits, A. N. Hoofnagle, L. Kooienga, R. Thadhani, M. Mannstadt, M.Wolf, and G. M. Chertow. 2012. Effects of Phosphate Binders in Moderate CKD. J. Am. Soc. Nephrol. 23:1407-1415. doi:10.1681/ASN.201 2030223

Boda, J. M., and H.H. Cole. 1954. The Influence of Dietary Calcium and Phosphorus on the Incidence of Milk Fever in Dairy Cattle. J. Dairy. Sci. 37:360-372.

Coburn, J. W., and S. G. Massry. 1970. Changes in serum and urinary calcium during phosphate depletion: studies on mechanisms. J. Clin. Invest. 49:10731087.

Cook, T. E., W. A. Cilley, A. C. Savitsky, and B. H. Wiers. 1982. Zeolite A hydrolysis and degradation. Environ. Sci. Technol. 16:344-350.

Corlett, S. C., M. Couch, A. D. Care, and A. R. Syke. 1990. Measurement of plasma osteocalcin in sheep: assessment of circadian variation, the effects of age and nutritional status and the response to perturbation of the adrenocortical axis. Exp. Physiol. 75:515-527. 
Enemark, J. M. D., A.M. Frandsen, T. Thilsing-Hansen, and R. J. Jørgensen. 2003. Aspects of physiological effects of sodium zeolite A supplementation in dry, non-pregnant dairy cows fed grass silage. Acta. Vet. Scand. Suppl. 97:97-117.

Ghijsen, W. E. J. M., M. D. de Jong, and C. H. van Os. 1982. ATP-dependent calcium transport and its correlation with $\mathrm{Ca}^{2+}$-ATPase activity in basolateral plasma membranes of rat duodenum. Biochim. Biophys. Acta. 689:327-336.

Goff, J. P., T. A. Reinhardt, and R. L. Horst. 1991. Enzymes and factors controlling vitamin $\mathrm{D}$ metabolism and action in normal and milk fever cows. J. Dairy Sci. 74:4022-4032.

Grabherr, H., M. Spolders, M. Furll, and G. Flachowsky. 2009. Effect of several doses of zeolite $A$ on feed intake, energy metabolism and on mineral metabolism in dairy cows around calving. J. Anim. Physiol. Anim. Nutr. 93:221-236. doi:10.1111/j.1439-0396.2008.00808.x

Herm, G., A. S. Muscher-Banse, G. Breves, B. Schröder, and M.R. Wilkens. 2015. Renal mechanisms of calcium homeostasis in sheep and goats. J. Anim. Sci.. 93:1608-1621. doi:10.2527/jas2014-8450

Hoenderop, J. G. J., A. W. C. M. van der Kemp, A. Hartog, S. F. J. van de Graaf, C. H. van Os, P. H. G. M. Willems, and R. J. M Bindels. 1999. Molecular identification of the apical $\mathrm{Ca}^{2+}$ channel in 1,25-dihydroxyvitamin $\mathrm{D}_{3}$ responsive epithelia. J. Biol. Chem. 274:8375-8378.

Hoenderop, J. G. J., B. Nilius, and R. J. M. Bindels. 2005. Calcium absorption across epithelia. Physiol. Rev. 85:373-422. doi:10.1152/physrev.00003.2004

Kallfelz, F. A., A. N. Taylor, and R. H. Wasserman. 1967. Vitamin D-induced calcium binding factor in rat intestinal mucosa. Proc. Soc. Exp. Biol. Med. 125:54-58.

Kamphues, J., M. Coenen, P. Wolf, A. Liesegang, K. Eder, K. Männer, C. Iben, Q. Zebeli, E. Kienzle, and J. Zentek. 2014. In: Supplemente zur Tierernährung (in German). 12th ed. M. \& H. Schaper GmbH, Hannover, DE. p. 279.

Kichura, T. S., R. L. Horst, D. C. Beitz, and E. T. Littledike. 1982. Relationships between prepartal dietary calcium and phosphorus, vitamin $\mathrm{D}$ metabolism, and parturient paresis in dairy cows. J. Nutr. 112:480-487.

Kovács, S., M. R. Wilkens, and A. Liesegang. 2015. Influence of UVB exposure on the vitamin $D$ and calcium homeostasis of growing sheep and goats. J. Anim. Physiol. Anim. Nutr. 99(Suppl. 1):1-12. doi: 10.111/jpn.12311 
Liesegang, A., M.-L. Sassi, and J. Risteli. 2003. Diurnal variation in concentrations of various markers of bone metabolism in growing female goats and sheep. Anim. Sci. 77:197-203.

Loffing, J., and B. Kaissling. 2003. Sodium and calcium transport pathways along the mammalian distal nephron: from rabbit to human. Am. J. Physiol. Renal Physiol. 284:F628-F643.

Maunder, E. M., A. V. Pillay, and A. D. Care. 1986. Hypophosphataemia and vitamin D metabolism in sheep. Q. J. Exp. Physiol. 71:391-399.

Naumann, K. and R. Bassler. 1997. Die chemische Untersuchung von Futtermitteln. 4. Ergänzungslieferung. VDLUFA-Verlag, Darmstadt, Germany.

Pallesen, A., F. Pallesen, R. J. Jorgensen, and T. Thilsing. 2008. Effect of pre-calving zeolite, magnesium and phosphorus supplementation on periparturient serum mineral concentrations. Vet. J. 175:234-239. doi:10.1016/j.tvjl.2007.01.007

Parson, D. S., and C. R Paterson. 1965. Fluid and solute transport across rat colonic mucosa. Q. J. Exp. Physiol. 50:220-231.

Peng, J. B., X. Z. Chen, U. V. Berger, P. M. Vassilev, H. Tsukaguchi, and E. M. Brown. 1999. Molecular cloning and characterization of a channel-like transporter mediating intestinal calcium absorption. J. Biol. Chem. 274:2273922746.

Rader, J. I., D. J. Baylink, M. R. Hughes, E. F. Safilian, and M. R. Haussler. 1979. Calcium and phosphorus deficiency in rats: effects on PTH and 1,25dihydroxyvitamin D3. Am. J. Physiol. 236:E118-122.

Rude, R. K. 2008. Magnesium Homeostasis. In: J. P. Bilezikian, L. G Raisz and T. J. Martin, editors, Principles of Bone Biology. 3rd ed. Academic Press, San Diego, CA. p. 487-513.

Schröder, B., G. Breves, and E. Pfeffer. 1990. Binding properties of duodenal 1,25dihydroxyvitamin $D_{3}$ receptors as affected by phosphorus depletion in lactating goats. Comp. Biochem. Physiol. A 96:495-498.

Schröder, B., H. Käppner, K. Failing, E. Pfeffer, and G. Breves. 1995. Mechanisms of intestinal phosphate transport in small ruminants. Br. J. Nutr. 74:635-648.

Schröder, B., W. Goebel, K. Huber, and G. Breves. 2001. No effect of vitamin $D_{3}$ treatment on active calcium absorption across ruminal epithelium of sheep. J. Vet. Med. A Physiol. Pathol. Clin. Med. 48:353-363. 
Scott, D., N. Loveridge, L. Nicodemo, W. Buchan, J. Milne, A. Duncan, P. Nicol, and S. P. Robins. 1997. Effect of diets varying in nitrogen or phosphorus content on indicators of bone growth in lambs. Exp. Physiol. 82:193-202.

Sidler-Lauff, K., A. Boos, M. Kraenzlin, and A. Liesegang. 2010. Influence of different calcium supplies and a single vitamin $D$ injection on vitamin $D$ receptor- and calbindin D9k-immunoreactivities in the gastrointestinal tract of goat kids. J. Anim. Sci. 88:3598-3610. doi.10.2527/jas2009-2682

Thilsing-Hansen, T., and R. J. Jorgensen. 2001. Hot topic: prevention of parturient paresis and subclinical hypocalcaemia in dairy cows by zeolite $A$ administration in the dry period. J. Dairy Sci. 84:691-693.

Thilsing-Hansen, T., R. J. Jorgensen, and J. M. D. Enemark. 2002. The effect of zeolite $A$ supplementation in the dry period on periparturient calcium, phosphorus, and magnesium homeostasis. J. Dairy Sci. 85:1855-1862.

Thilsing, T., R. J. Jorgensen, and H. D. Poulsen. 2006. In vitro binding capacity of zeolite $\mathrm{A}$ to calcium, phosphorus and magnesium in rumen fluid as influenced by changes in pH. J. Vet. Med. A Physiol. Pathol. Clin. Med. 53:57-64. doi:10.1111/j.1439.0442.2006.00798.x

Tschuor, A. C., B. Riond, U. Braun, and H. Lutz. 2008. Hematological and clinical biochemical reference values for adult goats and sheep. Schweiz. Arch. Tierheilkd. 150 :287-295. doi.10.1024/0036-7281.150.6.287

Wasserman, R. H., A. N. Taylor, and F. A. Kallfelz. 1966. Vitamin D and transfer of plasma calcium to intestinal lumen in chicks and rats. Am. J. Physiol. 211:419423.

Wilkens, M. R., N. Mrochen, G. Breves, and B. Schröder. 2011. Gastrointestinal calcium absorption in sheep is mostly insensitive to an alimentary induced challenge of calcium homeostasis. Comp. Biochem. Physiol. B Biochem. Mol. Biol. 158:199-207. doi.10.1016/j.cbpb.2010.11.008

Wilkens, M. R., J. Richter, D. R. Fraser, A. Liesegang, G. Breves, and B. Schröder. 2012. In contrast to sheep, goats adapt to dietary calcium restriction by increasing intestinal absorption of calcium. Comp. Biochem. Physiol. A Mol. Integr. Physiol. 163:396-406. doi.10.1016/j.cbpa.2012.06.011 


\section{Danksagung}

An dieser Stelle möchte ich allen ganz herzlich danken, die in irgendeiner Form zum Gelingen meiner Doktorarbeit beigetragen haben!

Mein besonderer Dank geht an:

Prof. Dr. Annette Liesegang für die Überlassung des interessanten Themas, für die fachliche und praktische Unterstützung, für die sorgfältige Durchsicht der Arbeit und für alles Andere.

Dr. Mirja Wilkens, für fachliche und praktische Unterstützung beim Schlachten, bei PCR und Western blot und beim Schreiben des Manuskripts.

Maja Bollhalder für die unermüdliche Unterstützung bei PCR und Western blot. Für ihre unendliche Geduld, als meine schon längst ausgeschöpft war.

Ines Mittner für die zügig erledigten Laborarbeiten und die Geduld während der Zeit der Ussing-Kammer-Untersuchungen.

Meinen Mitdoktoranden Martina Kohler, Gudrun Fechner, Driton Haxhiu, Claudia Keller, Sandra Kovács und der Postdoc Kathrin Bühler für die tatkräftige Unterstützung bei den Probenentnahmen, auch zu unangenehmen Tageszeiten.

Ausserdem für die Kameradschaft, angenehme Zusammenarbeit, die gute Stimmung im Büro und die moralische Unterstützung.

Dem Team vom Physiologischen Institut in Hannover für die Hilfe bei den PCR und Western blots.

Den Metzgern Paul Müller und Peter Bänziger für das kompetente Schlachten der Tiere und das Ausbeinen der Knochen.

PD Dr. Fredi Jannett für die Bereitstellung des flüssigen Stickstoffes.

Katrin Süss für die Präpariertische und das Sezierbesteck.

Den Tierpflegern Joanna Schmid und Holger Born für die Betreuung der Tiere und Hilfe bei der Probenentnahme.

Meinen Eltern für die bedingungslose Unterstützung in allen Lebenslagen. 